DOI: 10.20472/IAC.2017.034.020

ATULAN GUHA

Indian Institute of Management Kashipur, India

\title{
ROLE OF FOREIGN EXCHANGE RESERVE IN EXCHANGE RATE BEHAVIOUR THE PERSISTING ASYMMETRY: A HISTORICAL ACCOUNT
}

\begin{abstract}
:
Foreign exchange and monetary gold reserve is a very important factor to determine nominal exchange rate for the countries whose currency has very little use as reserve currency. Whereas, for the reserve currency countries it is not so important -it is primarily because of their greater money pulling power internationally through rate of interest change. They have this power because their currencies are having greater use as international money. Though the international monetary systems have changed from fixed exchange rate of Gold Standard period to independent float or managed float exchange rate systems of today's world, this asymmetry between the reserve currency countries and the other countries has not change. Though, ideally under flexible exchange rate system, the importance of foreign exchange reserve in determining nominal exchange rate should be very little. This paper takes an historical review of all the International Monetary System to establish the importance of foreign exchange reserve in determining exchange rate for developing countries; but it is not be the case with the reserve currency countries.
\end{abstract}

\section{Keywords:}

Exchange Rate, Foreign Exchange Reserve, fixed exchange rate, flexible exchange rate

JEL Classification: F31, F33, F41 


\section{Introduction}

To explain the movement of exchange rate behaviour the role of foreign exchange and monetary gold reserve has been neglected in the theories of exchange rate behaviour. Either it has been excluded as a determinant or treated as merely a residual factor. But historically and in the present context foreign exchange and monetary gold reserve has played a reasonably important role in determining nominal exchange rate of the countries. More specifically it is true for the developing countries. It may not hold for the countries whose currency has a reasonable amount of use as international money. The currencies of countries who has economic and political hegemony, which often complement each other, has greater use as international money. For them the stock of foreign exchange and monetary gold reserve may not have much influence on exchange rate. In this paper we shall show historically as well as today how foreign exchange and monetary gold reserve is an important factor behind exchange rate movement for the developing countries but not so for the reserve currency countries. This asymmetry between the two categories existed during Gold Standard and Bretton Woods period. In post-Bretton Woods era the international monetary system has changed but this asymmetry persisted. Since, stock of foreign exchange and monetary gold reserve does not have considerable influence on nominal exchange rate of the advanced capitalist countries (whose currencies have substantially greater use as the reserve currency), may be in the theories of exchange rate movement its role is neglected. We shall proceed in our discussion according to historical sequence. First, we discuss the Gold Standard Period, followed by Bretton woods and then the present post-Bretton Woods era.

\section{The Gold Standard}

The basic structure of Gold Standard system indicated that large reserves were required to keep the exchange rate fixed. The exchange rates among national currencies were decided through the relative amount of gold promise against the currency notes by the respective Central banks - the exchange rate of a country was dependent upon its central bank's promise of the amount of gold to pay in exchange of one unit of currency and this rate was fixed. So, to keep the promise, Central banks were required to keep sufficient monetary gold reserve against their money in circulation. The exchange rate of a country would be destabilized if the claim of the foreigners on the gold due to holding of that country's money were more than the monetary gold reserve of the central bank. Thus, for instability of exchange rate, balance of payments (BoP) deficit would be a necessary condition. If a particular country had large monetary gold reserve that could cover the BoP deficit then the exchange rate of that country would be stable. So, to keep exchange rate stable, countries in practice had three options - keeping sufficient 
monetary gold reserve, adjustment through current account and adjustment through capital account.

Most of the theoretical analyses of this system state that the exchange rate was maintained through the adjustment in current account. For the monetarists school of thought if there is any disequilibrium in the BoP, the automatic adjustment in price will bring the required change in the BoP through an adjustment in the current account. Any disequilibrium in the BoP will have an impact on money supply and hence on price. This price change will bring a change in the trade account. This adjustment process is based on some questionable assumptions - the effect of gold inflow and outflow will be completely on price, not on output and second, price change will be enough to adjust the trade balance such that exchange rate remains at its original level. All these were doubtful assumptions in practice, not all of which were satisfied even in the classic period of the Gold Standard, and even less in the subsequent period leading to its breakdown in 1914. The other view considers the possibility of taking other routes, i.e. changes in aggregate demand, rather than price adjustment due to changes in money supply, will improve the current account. A reduction in aggregate demand might lower incomes and price and improve trade balance. The main argument against emphasizing this adjustment mechanism, however, is simply that it operated only with lags too great and too uncertain to account for the remarkably smooth and rapid pace at which exchange rates, international gold flows and gold reserves of central banks seem to have been altered generally during this period (Lindert 1969).

In practice, to adjust any disequilibrium in BoP, countries had either kept sufficient monetary gold and foreign exchange reserve or adjusted through capital account or followed both. Britain had adjusted any disequilibrium in BoP by changing capital flows through the policy of rate of interest change ${ }^{2}$. France and Germany had opted for both the options - keeping reasonably large foreign exchange and monetary gold reserve and rate of interest policy to change capital flows. The underdeveloped, dominions and colonial countries, in general, had to keep sufficiently large foreign exchange and monetary gold reserve to adjust with any disequilibrium in BoP.

The reason that only Britain could able to keep her exchange rate stable without keeping sufficiently large monetary gold reserve, was inherent in the structure of international finance, trade and politics of that period. It gave Britain far greater control over capital flows. Britain was the largest emperor, lender, trader, trade financier country in the world. It had largest financial security and gold market in the world. Britain had an unmatched supremacy in financing the world trade. In 1914, the international trade bills financed by London stood at 350 million pounds (Cassis, 2011). ${ }^{3}$ It controlled a large empire, which

1 Scammel (1985)

2 It is evident from the writings of Lewis (1978), De Cecco (1984), Scammel (1985) and Keynes (1913).

${ }^{3}$ Aliber has said "Traders in foreign exchange need an inventory of foreign currencies; they want to minimize the cost of holding this inventory. The costs of holding this inventory could be minimized if the currencies are denominated in the 
could be forced to make payments such as the Home Charges in British sterling. Finally, Britain had a large current account surplus throughout this period. Even though it had a trade deficit, it had current account surplus, due to huge net factor income, mainly from interest earning. This high interest earning might have been also a major incentive for high foreign lending by Britain.

All these factors together resulted in one dominant feature characterizing the international money market of that time - British Sterling became the most accepted medium of exchange worldwide and it had consequent in creation of international confidence on the stability of exchange rate of sterling vis. a vis Gold. As a result, on an international scale, British Sterling could function in practice as a reserve currency along with gold. With the British Sterling starting to function as reserve currency, central banks of other countries had the option of choosing the composition of the reserve fund, whether it should contain more gold or sterling holding. The reason behind holding the Sterling (except US.) was that gold did not earn any interest while Sterling deposits did earn interest. The formal and informal British Empire, extending over parts of Africa, Asia and Australia further contributed to this process. In 1913, together these countries held about 150 million dollars worth of Sterling deposits in London. Apart from these colonies and dominions, the independent countries also held Sterling deposits in London. The Japanese government and Bank of Japan had together held deposits in London worth of 101.1 million dollars, the National Bank of Greece around 10 million dollars and other European monetary authorities together also had deposited around 100 million dollars, in 1913. It showed that apart from gold, it was the British-sterling about which the international money market had the confidence that its value would be stable and would be easy to convert into gold. In short, it had greater liquidity. It helped Britain to have greater money pulling power (Keynes (1913), Guha, 2007).

The mechanism by which London pulled money internationally was the interest rate policy of central bank, but, other countries were not successful to use this for the same purpose. Higher interest rates in London would attract short-term capital from abroad or prevent it from going abroad, since the probability of exchange gains was high ${ }^{4}$. But, there are differences of opinion about how it had worked. According to Keynes, it was because of their short-term creditor position of Britain. But contradictory evidences to the

currency of the country identified with low interest rates. Before World War I, a large part of international trade was denominated in the British pound; since then much of the international trade has been denominated in the US dollar. Importers in many countries (except primarily US) need to pay US dollars; exporters in these countries receive US dollars. So these traders began to acquire the US dollar deposits as part of their inventory. And the development of the reserve currency roles of the British pound and then of the US dollar followed the patterns of trade finance" (Aliber 2000, ).

${ }^{4}$ Lewis (1978). He said, "Whenever Britain began to recover from cyclical recession there would come a point where the Bank began to lose gold.... A financial crisis could occur... The bank rate would go sharply, and open market operations or equivalent would be launched. At this point oversees lending would be suspended because the stock exchange would react to the financial crisis, because the houses promoting such loans would think the moment inauspicious, and because those who held funds for foreign countries would keep them in London to earn higher interest rate. 
claim of Britain's position as a short-term net creditor are provided by Lindert (1969) and De Cecco (1984). Lindert (1969) has claimed that Britain's greater money pulling power could be due to greater liquidity of the British Sterling denominated assets, which were followed in this respect by assets denominated in the Frank and Mark. It also implies that BritishSterling had a greater use as an international reserve, which implies greater confidence in the stability of the exchange rate, and greater money pulling power. According to De Cecco (1984), such a degree of confidence can be reached when lesser countries were politically or economically subservient. These countries were denied the right to choose between gold and Sterling; they had to deposit any surplus, in Sterling, in London. At the same time London held deposits of the independent countries, which could exercise the right to choose between gold and Sterling whenever they wanted. This can be explained by the fact that this dominance had made British Sterling the reserve currency there was a confidence in the stability in the value and liquidity of the Sterling denominated assets so that more reserve flowed into London. In effect it helped Britain to have an effective rate of interest policy to attract money towards it from the continent, which was the source of funds for the short-run adjustment in British reserve as Lindert (1969) mentioned.

In conclusion, the hegemony over world trade and finance and control over economic and politically subservient countries had led to an international arrangement in which the British Sterling found wide spread acceptance as reserve currency. All of these factors helped Britain to have extraordinary money pulling power on an international scale at the height of the Gold Standard. As a result, Britain could sustain the stability of its exchange rate without having large reserves and stability in exchange rate itself had helped it to maintain the confidence in Sterling, which helped its use as reserve currency.

Apart from Britain, France and Germany were also lender countries. Yet none of them managed to rival London in the business of accepting and discounting foreign trade bills or in the volume of total foreign lending. France's share in total world trade was also small compared to Britain. The money deposited in these countries by other countries was quite small compared to Britain. In 1912 only 1235 million francs were deposited in Paris, in Berlin it amounted to only 152.3 million dollars in December 1913 (Keynes, 1913). The liquidity of Franc-denominated and Mark-denominated assets was less than of those denominated in the Sterling. The Central banks of these countries sometimes had partially stopped the convertibility into gold. All these were reasons contributing to the lesser international demand for these two currencies as medium of exchange. This, in turn, contributed to the failure in generating such a confidence in these currencies that they could be used widely as reserve currencies. Consequently, neither Paris nor Berlin succeeded in matching the international money pulling power of London. In contrast, the extent of the use of a currency as an international medium of exchange and its use as a store of wealth: both these factors worked together, hand in hand, for Britain. Though, from time to time, Germany had tried to use the bank rate device, its extent was limited. And the capital inflows were not sufficiently large to solve the BoP deficit problem 
(Bloomfield 1963, 70). Thus, even France and Germany had to keep large monetary gold reserves, compared to Britain, to defend their currency. This was even truer for the countries, which were in the third tier of financial centers.

According to Keynes' (1913) narration the majority of the European countries, for example, France, Austria-Hungary, Russia, Italy, Sweden or Holland had a gold currency and an official bank rate. In none of them gold was the principal medium of exchange and in none of them bank rate was not the 'habitual support' to prevent outflow of gold. All these countries had three options to maintain the exchange rate parity - maintenance of very large gold reserve, partial suspension of free payments in gold may be and keeping highly liquid foreign credits and bills. The Bank of France used the first two. Its bank rate was not fixed primarily with a view of foreign conditions and a change in it is usually intended to affect the domestic economy. Germany attempted to bank upon the bank rate to attract capital flow to ease off the pressure from the exchange rate parity but it was not very successful. Its gold reserve was not large enough. Free payment in gold was sometimes suspended, like in November 1912. To an increasing extent German central bank depended on variation in her holding of foreign bills and credits which could be utilized at the time of stringency. For example, in the third quarter of 1911 the Bank had placed a minimum amount of 4,000,000 pounds gold bills at the disposal of the AustroHungarian market in order to support the exchange. In November 1912, Russia had as foreign bills balances an amount of $26,630,000$ pounds. During the same period three Scandinavian countries, Sweden, Norway and Denmark held the highest proportion in the form of balances abroad (Keynes, 1913).

The reason for keeping a high portion of reserves as foreign currency denominated assets by these countries was that the money market was not so developed that it could work as a lender or to be at least self-supporting. The Central banks to make them secure, had to enter the international money market as short-term creditor, that they could take out money at short notice. The only alternative would have been the holding of a much larger reserve of gold, the expense of which would have been nearly intolerable.

It was impossible to use of the currencies of the countries more peripheral to the system as international reserve currency. In fact they had to keep large part of their reserve not into gold but as Sterling deposits in London or to invest into the security market of developed countries, mainly in London. Their role in international finance was to get themselves exploited and by this serve the interest of the financial centers. Typically they were forced to provide money to the financial centers. Thus India provided money to London, financial center. India had been one of the worst exhibitions of imperial exploitation. The reserves, on which the Indian monetary system was based, used to supplement Britain's reserve and majority of it was invested in London financial market. Apart from this, Britain used to have two other channels, through which she could improve her BoP by using India's colonial status. The first was the Home Charges and 
second was through balance of trade. The Home Charges consisted mainly of interest on debts to England incurred by the British Raj, pensions of former Indian civil servants living in England, payments to the war office for upkeep of the Indian Army and of the whole imperial Army and purchase of materials in England on the Raj's account. India's foreign trade was structured in such a way that India had a huge trade deficit with Britain and had huge trade surplus with the rest of the world (Saul 1960, Guha 2007).

At the same time, politically independent but economically weaker countries, like Argentina, could not keep large reserve. This was because keeping large reserves for them was very costly, somewhat similar to 'a man borrowing at 6 per cent to keep money in the bank at 3 per cent'. Most of these countries had rather underdeveloped banking systems. They could not effectively influence their financial markets. Even if their Central banks tried to use the bank rate to cover the deficit on the BoP with a view to stabilizing the exchange rate, they were doomed to failure. So, the safe policy options for these countries for currency stability were -keeping a BoP surplus or keeping a critical level of reserve such that the intervention in the exchange market could be effective to have stable currency.

To Summerise, during the Gold standard period the adjustment through the current account did not have a reasonably important role in exchange rate management. The stability of the exchange rate was scarcely dependent on foreign exchange and monetary gold reserves in the case of Britain which was the dominant economic power of the time. Britain had managed the stability of exchange rate through its manging capital flows by alterring bank rates. The stability of the exchange rate of other countries, especially underdeveloped and colonial countries depended upon the stock of reserves they had. This asymmetry between then reserve currency British Sterling and others had arised primarily from the ability of the countries control capital flows.

\section{The Bretton Woods}

According to the structural norms of Bretton Woods system, the direct link between exchange rate and monetary gold reserve, which was existed in Gold Standard system, was broken, except for US Dollar. Except USA, all other countries had to fix, at a level fixed by International Monetary Fund (IMF), a par value for its currency in terms of the US Dollar. Every country had to keep its exchange rate within 1 per cent of its par value, but retained the right to adjust its central parity, upon securing the concurrence of the IMF, if ever a 'fundamental disequilibrium' developed in its BoP. Thus all the other countries were indirectly linked with monetary gold reserve via the US dollar. 
But none of the countries actually changed their parity very flexibly such that market exchange rate would lie within the band of $1 \%{ }^{5}$. Apart from the exception of transitional arrangement permitting a one-time adjustment up to ten per cent in the initial par values, members would change their par values only after having secured IMF approval. The approval would be given only if the country's BoP were in 'Fundamental Disequilibrium'. So countries were required to keep sufficient reserves to maintain the officially declared par value.

In Bretton Woods regarding the convertibility of currencies it was envisaged that after a transitional period countries would undertake to redeem balances of their currencies acquired by other members. Such convertibility would be into either gold or the currency of the member requesting conversion. Restriction on payments for current transactions and all discriminatory currency practices were to be discouraged if not eliminated. Though there were restrictions on capital flows, such flows were not totally stopped. There was a significantly large US investment undertaken abroad. This was done by the UK also but to a lesser extent.

Though under the Bretton Woods system current account convertibility was accepted in principle, in practice most of the countries had imposed restrictions on current account transactions. The industrial countries of Western Europe had removed the current account restrictions under the obligation of Article VIII of IMF by 1961. Apart from few developing countries like, Mexico etc., most of them had restrictions in current account transaction.

The industrial countries of Western Europe had to keep a reasonably large amount of foreign exchange and gold reserves. Otherwise they would face problem to maintain the exchange rate parity. In the decade of 1960s, we found that almost all of these countries had better ratio of foreign exchange reserve to money supply (including monetary gold reserves in the foreign exchange reserve) than USA. In fact whenever their ratio declined persistently and come down to a little over 0.06 , these countries including the U.K. and France, had to devalue their currency. But the only exception was USA. Its low ratio continued for a very long period. Until USA's ratio went down further to 0.02 , it did not devalue its currency. Though the UK had a higher reserves-money ratio compared to the USA it had low reserves-money ratio (ranging from 0.09 to 0.06 ) compared to other countries for a long period. So UK could also defer the depreciation for a longer period in compared other developed countries of Western Europe. This duration of deferment of depreciation was less than the USA (calculated by the author using International Financial Statistics of IMF).

\footnotetext{
5 The countries that had balance of payment surplus for long time were reluctant to appreciate their currency. There were no provisions in Bretton Woods system, which could force the stronger currency like Deutschmark to appreciate. According to the US it was one of the reasons behind the losing of US trade competitiveness to Western Europe. Many of the deficit countries were reluctant to depreciate their currency. The major reason was the import of essential goods and services would have costlier and lead to the inflation in the economy. Also depreciation of the currency was seen as national shame.
} 
In fact the number of cases where the currencies of developed countries were devalued was much smaller than the developing countries. Margaret G. de Vries ${ }^{6}$ has mentioned that the industrial countries undertook relatively little devaluation of their exchange rates. Of the fourteen members of the Fund classed as industrial countries in 1965, only five altered their exchange rates between September 1949 and the end of 1965. Germany and Netherlands had appreciated their currencies in 1961. Austria devalued its currency by stages until 1953. France devalued twice. Canada devalued once, by a small amount in 1962. However, many less developed countries had experienced a greater frequency and level of exchange rate depreciation than was often realized. Countries in Africa, Asia, Latin America and the Middle East, undertook several exchange rate adjustments. Among a third group of countries, classed as primary producing but more developed, exchange rate devaluation was not uncommon (Data Source: International Financial Statistics of IMF).

Now the question is why this was happened? This reason was that US Dollar was being the only official reserve currency along with Gold. It led to the general use of the US Dollar by foreign Governments and Central Banks as reserve asset. The presumption of unchanged parity applied with particular force to the Dollar. It was generally assumed that the effective exchange rate of the dollar would never change either through a deliberate devaluation initiated by the USA or by virtue of a general appreciation of other important currencies. The assumed invulnerability of the dollar's parity was the reason behind the US capability of keeping a low foreign exchange reserve to money supply ratio (including monetary gold) for such a long period without devaluing the currency- even though it had BoP deficit for a long period. It allowed the US to buy around the world for a long period, as every other country was willing to hold Dollar as an asset. As pound-sterling also used as a reserve currency to a limited extent in comparison to USA, UK could keep a high ratio of money supply to foreign exchange reserves including monetary gold for a significantly long period without having exchange rate depreciation. (Though this period was shorter than USA) Other industrial countries that adopted the obligations under Article VIII of the IMF by 1961 were much more disciplined in terms of not keeping BoP deficit persistently. Very few of the developing countries ${ }^{7}$ had accepted the obligation under article VIII. These countries had restrictions on exchange transaction. So for them it was not required to have a sufficient portion of reserve as foreign exchange and monetary gold reserves. But these countries had to devalue their currencies frequently when they were unable to pay their import bill for a longer period. They did not have the luxury of keeping persistent BoP deficits with stable exchange rates as the USA had. Mexico, which had accepted the obligations under Article VIII, had kept a low ratio of

\footnotetext{
${ }^{6}$ De Vries, Margaret G. and J. Keith Hoschield, (1969) " The International Monetary Fund 1945-1965, Twenty Years of International Monetary Co-operation", Vol. II, pp 111-112

${ }^{7}$ The countries that accepted the article VIII obligations by 1965 were Costa Rica, Dominican Republic, El Salvador, Guatemala, Haiti, Honduras, Jamaica, Panama, Peru, Mexico, Kuwait, Saudi Arabia and Nicaragua. Source: De Vries, Margaret G. and J. Keith Hoschield, (1969)
} 
money supply to foreign exchange reserves including monetary gold. Also it did not have persistent BoP deficit though its balance of trade and current account was in deficit.

In conclusion, the stability of the exchange rate was not particularly dependent on foreign exchange and gold reserves in the case of the USA as it was the dominant economic and political power of the time. For other countries stability of the exchange rate was dependent upon the stock of foreign exchange and gold reserves in possession of the country concerned. This difference in the link between reserves and national currency was dependent crucially upon the extent to which a country's currency was used as international money. After the World War II, the USA was the dominant economic power. In fact it was the only major economy to have benefited from the war. The extraordinary superiority of the US in the depths the global conflict could be demonstrated in virtually every economic variable, which symbolizes power, one could think of. It had a marked advantage in labour productivity for a long period, underlining the organizational and technological basis of its dominance. In terms of sheer size the US economy was almost five times larger than other major economy U.K. Compared to Germany or France it was more than six times larger (Source: Maddison, A (1987), table A-1, p. 682). America had become the workshop of the Allied war effort and the demand for its food and capital goods would remain strong after the war. Its goods having captured new overseas markets, its merchant fleet became unrivalled and resulted in a huge surplus in balance of trade. US controlled more than $80 \%$ of the non-socialist gold ${ }^{8}$. It was the US which actually financed the recovery expenses of the war-devastated Western European countries through different grants (Marshall Aid ${ }^{9}$ ). There is little doubt that the US economic and financial power has played a major role in shaping the postwar international monetary system. As a result the US Dollar had replaced the British sterling as a reserve currency. It was done through formal means, that is. the Bretton Woods negotiations. So the US Dollar was used as reserve currency officially apart from gold. In general, a country, which had more influence on world trade and finance, was also correspondingly more able to create the presumption that its currency was more stable. As a result the US Dollar had very wide use as international money. This gave rise to an apparently paradoxical pattern: the more economically powerful a country, the less it needed to maintain reserves to back its currency, the extreme case being that of USA. This asymmetry persisted in the period of the Gold Standard. It had persisted in the period of Bretton Woods system. Both the systems of fixed exchange rate have disappeared, and a new system of flexible exchange rate has been introduced in the post Bretton Woods era. In the next section, we shall examine whether the above mentioned asymmetric rules of the game has survived in post Bretton Woods flexible exchange rate system.

\footnotetext{
${ }^{8}$ Bhaduri, Amit. (1986), "Macroeconomics: The Dynamics of Commodity Production", Macmillan, Delhi

9USA under Marshall Plan between 1948-52 provided Western Europe with massive bilateral aid of amount US 17 billion dollar.
} 


\section{The Post-Bretton Woods Era}

In the flexible exchange rate system of Post-Bretton Woods era the link between exchange rate and the stock of reserve that was existed in Gold Standard and Bretton Woods system due to the basic structural norms of those systems, was broken. After initial two decades of transition period, for most of the countries exchange rate gets determined in the foreign exchange market. Even so, the countries are having exchange rate system of either the managed float or independent floating ${ }^{10}$. As many countries are following various degree of pegged exchange rate system the stock of reserve is continuing to be an important factor behind the stability of the exchange rate. Even the countries that follow independent floating exchange rate system have preserved the Central Bank's right to intervene in the foreign exchange market or they have sizeable intervention in the foreign exchange market ${ }^{11}$. So foreign exchange reserve should continue to be one of the important factors behind the exchange rate stability.

Now the question is there any variation among countries to hold foreign exchange reserve. If we look at the data provided by COFFER, IMF, the industrial nations together in 1995 were holding 47.5 per cent of global foreign exchange reserve. At the last quarter of 2007, they were holding only 23.5 per cent of global foreign exchange reserve. During this whole period, the world foreign exchange reserve has grown at the annual average of 4.05 per cent. During the same period, foreign exchange reserve for the industrially developed nation has grown at the annual average of 2.49 per cent and for the developing countries it has grown at 4.78 per cent.

Table 1: Foreign Exchange Reserve - GDP Ratio (in per cent)

\begin{tabular}{|l|l|l|l|l|l|l|l|l|l|}
\hline & 2005 & 2006 & 2007 & 2008 & 2009 & 2010 & 2011 & 2012 & 2013 \\
\hline United Kingdom & 1.59 & 1.58 & 1.65 & 1.59 & 2.41 & 2.84 & 3.06 & 3.39 & 3.45 \\
\hline United States & 0.41 & 0.40 & 0.41 & 0.45 & 0.83 & 0.81 & 0.88 & 0.86 & 0.80 \\
\hline${ }^{*}$ Euro zone & 1.43 & 1.44 & 1.36 & 1.20 & 1.81 & 1.97 & 1.95 & 2.22 & 2.12 \\
\hline $\begin{array}{l}109 \text { non-reserve } \\
\text { currency } \\
\text { countries }\end{array}$ & 10.55 & 12.12 & 14.31 & 13.60 & 15.76 & 15.03 & 14.10 & 13.55 & 13.02 \\
\hline
\end{tabular}

Source: Calculated by the Author using International Financial Statistics, IMF

${ }^{*}$ Euro zone currently have 19 countries. 7 of them has joined the zone during the period of 2005-15. So we have excluded them to bring consistency between 2005 and 2013.

The most important reserve currency country is United States and its foreign exchange reserve- GDP ratio is lowest in the world. In the year 2005, it was only 0.41 percent. In

\footnotetext{
10:Economic Report of the President, USA, 2007, PP. 161,

Web link: http://www.gpo.gov/fdsys/pkg/ERP-2007/pdf/ERP-2007-chapter7.pdf

${ }^{11}$ :Economic Report of the President, USA, 2007, PP. 161,

Web link: http://www.gpo.gov/fdsys/pkg/ERP-2007/pdf/ERP-2007-chapter7.pdf
} 
the subsequent period till 2013, this ratio took highest value of 0.88 per cent (Table1). The second most important reserve currency is Euro. In the year 2005 for the Euro zone, the foreign exchange reserve-GDP ratio was 1.43. And during the period of 2005 to 2013, the maximum value it took was 2.22. Another important reserve currency is BritishSterling. During the period of 2005 to 2013, its foreign exchange reserve- GDP ratio has varied between 1.58 to 3.45 per cent. Whereas, for 109 (for whom we could get consistent data on GDP and foreign exchange reserve for the entire period of 2005 to 2013) non-reserve currency countries, the foreign exchange reserve-GDP ratio has varied between 10.55 to 15.76 per cent during the same period of 2005 to 2013 .

Historically, we are seeing that reserve currency countries are keeping lower foreign exchange reserve compare to others. Simultaneously, these are the countries who has the effective of the interest rate policy to attract capital flows and the developing countries' interest rate policy are ineffective to attract capital flows ${ }^{12}$. This essentially indicates that the reserve currency countries can attract capital flows whenever they require foreign exchange. As a result, requirement for high level of foreign exchange reserve is less for them. But the question is why the reserve currency countries has more effective interest rate policy to attract capital flows. Capital flows into a country for two motives - income earning and capital gaining. If the income earning motive is the dominant one, capital flows will be sensitive to the rate of interest change and insensitive to exchange rate change. And if capital gaining is the dominant motive, capital flows will be sensitive to exchange rate change and insensitive to rate of interest change. It is expected, as we have seen in gold standard period and in current post-Bretton Woods era, that certain countries' (more specifically, reserve currency countries) rate of interest policy is relatively more effective to attract capital flows compared to that of rest including the developing countries. On the other hand, the capital flows that come into the countries, belong to 'rest', are more sensitive to exchange rate change.

A plausible answer to why capital flows are insensitive to real rate of interest change for 'rest' but sensitive to such real rate of interest change for reserve currency countries may be lying on the fact that - as the currencies of reserve currency countries are getting used as international money it creates the expectation of greater stability in their currency

12 The detailed empirical evidence are provided in Guha (2002). Also we see other kind of evidences, some of them are as follows-

1) The trigger to second Mexican currency crisis was the increase in interest rate by the Fed.

2), Rakshit (2002) -

The severity of external credit crunch a country faces following some large negative shock depends also on the country's standing in the international financial market. When faced with pressing balance of payments problems, along with depressed economic conditions at home, Great Britain or France could in early 90s have kept their currencies within the ERM band by inducing capital inflows through jacking up interest rates, provided they were prepared to endure a prolonged spell of unemployment and output loss. However, even though the long term fundamentals of South Korea, Malaysia and Thailand were stronger, at least not worse than the European economies in distress, the former failed to attract foreign capital even when their interest rate went through roofs. (Rakshit, 2002)

3 ) on $29^{\text {th }}$ June, 2015 the finance secretary of Govt. of India issued a statement that the Govt. of India is fearing capital outflow from India as the interest rate in EURO zone may go up due to Greek crisis. 
value. It makes the currency of these countries more stable and for the foreign investors it discourages the capital gains motive. So capital flow is less sensitive to the exchange rate change of these countries. For 'rest' of countries the exchange rate fluctuates much more compared to the reserve currency countries. So even if the rate of interest increases in the 'rest' of the countries the foreign investors are unsure about the return because of high exchange rate fluctuations. It is this which explains why in developing countries capital flows are more sensitive to the percentage change in exchange rate than the rate of interest differential ${ }^{13}$.

Now the currencies of the certain countries, who dominate the world economic-political order have much greater use as international money compared to 'rest' including the developing countries. They have a very large use as international medium of exchange as well as reserve currency (Table 2); this is due to the store of value as well as medium of exchange functions. Usually, the currency, which perform these two functions also serve as a unit of account. All these functions require stability in the value of the currency. So a greater use of a currency as international money requires a greater stability in its value. Since the currencies of the reserve currency countries have much greater use as international money the general expectation is that these countries' exchange rates are more stable compared to 'rest'. This has led to greater money pulling power for reserve currency countries through interest rate. It resulted for them a less requirement of keeping foreign exchange reserve.

Table 2

The Role of Different Currencies as International Currency in 2010

(as a share of a currency in total use)

\begin{tabular}{|l|l|l|}
\hline Currency & $\begin{array}{l}\text { Allocated Foreign Exchange } \\
\text { Reserves held by Central Bank* }\end{array}$ & $\begin{array}{l}\text { Foreign exchange trading in world } \\
\text { markets }^{* *}\end{array}$ \\
\hline US Dollar & 0.62 & 0.85 \\
\hline EURO & 0.26 & 0.39 \\
\hline Pound sterling & 0.04 & 0.19 \\
\hline Others & 0.05 & 0.44 \\
\hline
\end{tabular}

Source: * COFER, IMF

${ }^{* *}$ Central Bank Survey of Foreign Exchange and Derivative Market Activity, BIS, 2010

Whereas, the currencies of the 'rest' have hardly any use as international money. It led to a situation, where hardly they have any control over capital flows through rate of interest change. And capital flows are taking place because of exchange rate fluctuation. In this situation, among the 'rest' who has current account deficit, the only factor that can

13 Source: Guha Atulan (2002), "Some Persisting Asymmetries in International Finance: A Historical and Quantitative Exercise" unpublished Ph.D. thesis at Centre for Economic Studies and Planning, Jawaharlal Nehru University, New Delhi 
stabilise the exchange rate for them is a reasonable amount of foreign exchange reserve. So, though the international monetary system has changed, the asymmetries among the countries in terms of having requirement of foreign exchange reserve to keep the nominal exchange rate stable has persisted. This importance of foreign exchange reserve on exchange rate has been largely missing in the theories of exchange rate.

\section{Conclusion}

From our discussion of all the three international monetary system we can argue that foreign exchange and monetary gold reserve is a very important factor to determine nominal exchange rate for the countries belong to 'rest'. Whereas, for the reserve currency countries it is not so important -it is primarily because of their greater money pulling power internationally through rate of interest change. They have this power because their currencies are having greater use as international money. Though the international monetary systems have changed from fixed exchange rate of Gold Standard period to independent float or managed float exchange rate systems of today's world, the asymmetry between the reserve currency countries and 'rest' has not change. Against exchange rate volatility, the only defence of developing countries is having sufficient foreign exchange reserve. It does not have the luxury of using interest rate policy to attract capital flows to stable the exchange rate volatility. The speculative nature of capital flows has created this situation for the developing countries.

\section{References}

Aliber, R.Z, (2000) "Editor's introduction" in International Finance, an Edger Elger publication

Bhaduri, Amit. (1986), Macroeconomics: The Dynamics of Commodity Production, Macmillan, Delhi

BIS , Central Bank Survey of Foreign Exchange and Derivatives Market Activity, 2013.

Bloomfield, (1963) A. Short Term capital Movements under the Pre-1914 Gold Standard, Princeton Studies in International Finance, 11

Cassis, Youssef (2011) Crises and Opportunities: The Shaping of Modern Finance, Oxford University Press

De Cecco, M. (1984). The Gold Standard Money and Empire. London; Frances Pinter

De Vries, Margaret G. and J. Keith Hoschield, (1969). The International Monetary Fund 1945-1965, Twenty Years of International Monetary Co-operation, Vol. II

Dominguez, K and Frankel, J A (1993), "Does Foreign Exchange Intervention Matter? Disentangling the Portfolio and Expectation Effects for the Mark", NBER Working Paper

Economic Report of the President, USA, 2007, PP. Ch. 7. 
Web link: http://www.gpo.gov/fdsys/pkg/ERP-2007/pdf/ERP-2007-chapter7.pdf

Edwards, Franklin. (1993), "Financial Markets in Transition - or the Decline of Commercial Banking", Symposiumin Federal Reserve Bank of Kansas City,.

Guha, Atulan (2002), "Some Persisting Asymmetries in International Finance: A Historical and Quantitative Exercise" unpublished Ph.D. thesis at Centre for Economic Studies and Planning, Jawaharlal Nehru University, New Delhi

Guha, Atulan (2007), Exchange Rate Management in Gold Standard Era: A Historical Overview, Economic and Political Weekly,Vol - XLII No. 45-46, November 10, 2007

Keynes, J. M. (1913). Indian Currency and Finance

Lewis, W.A. (1978) "The evolution of the International Economic Order", Princeton University Press

Lindert, P.H. Key Currencies and Gold 1900 - 1913, Princeton Studies in International Finance, No.24.

Rakshit, M.(2002) The East Asian Crisis, Oxford University Press

Saul, S.B. (1960) Studies in British Overseas Trade Liverpool Univ. Press

Scammel, W. W. (1985). "The Working of Gold Standard" in Barry Eichengreen (Ed) The Gold Standard in Theory and History, New York: Methuen

World Bank, (1997).Private Capital Flows to Developing Countries: The Road to Financial Integration, Policy Research Report.Washington D.C., World Bank 